\title{
DINAMIKA KEHIDUPAN SOSIAL BUDAYA ETNIS TIONGHOA DALAM BINGKAI KEBIJAKAN ASIMILASI ORDE BARU (1966-1998)
}

\author{
Levia Chessiagi, Wawan Darmawan, Tarunasena \\ Universitas Pendidikan Indonesia
}

\begin{abstract}
TThis research titled "The Dynamics of SocioCulture Life of Chinese Ethnic in Frames of Assimilation Policy by the New Order Government (1966-1998)". The background why researcher took this problem is due to the interest in the condition of Chinese ethnic and the assimilation policy that applied by New Order Government. The application of assimilation policy has an impact on the limited space of Chinese ethnic lives. The main issue that examined in this research is "How was the New Order Government applied the assimilation policy toward Chinese ethnic in Indonesia specially in socio-culture aspect in 1966-1988?" This problem was examined by using the historical method that divided into four steps: Heuristic, Critic, Interpretation, Historiography. As for the data collection that used is literature studies by examining many literature sources which relevant with the topic. Based on the results, could be explain that First New Order Government applied the assimilation policy influenced by the idea of Chinese figures and made the ide as an official policy to resolve problems of Chinese ethnic that had long been happened in Indonesia. Second, the implementation of assimilation policy was experienced some obstacles and caused some problems on its implementation. Third, assimilation policy in social-culture aspect gave the negative impact that limiting the movement of Chinese ethnic in various areas of life, but gave them the room in economic aspect, assimilation policy was also giving the positive impact in creating multicultural society. The results of this study can be seen that the mutual respects were needed for the creation of harmony between communities in the country.
\end{abstract}

Keywords: Chinese ethnic, Assimilation policy, New Order
Penelitian ini berjudul "Dinamika Kehidupan Sosial Budaya Etnis Tionghoa dalam Bingkai Kebijakan Asimilasi Orde Baru (1966-1998)". Latar belakang peneliti mengambil permasalahan ini ialah karena adanya ketertarikan terhadap kondisi etnis Tionghoa masa Pemerintahan Orde Baru dan kebijakan asimilasi yang diterapkannya. Penerapan kebijakan asimilasi tersebut memiliki pengaruh terhadap terbatasnya ruang gerak kehidupan etnis Tionghoa. Masalah utama yang dikaji dalam penelitian ini ialah "Bagaimana Pemerintah Orde Baru menerapkan kebijakan asimilasi terhadap etnis Tionghoa di Indonesia pada bidang sosial dan budaya tahun 19661998?". Permasalahan tersebut dikaji dengan menggunakan metode historis yang terbagi ke dalam empat langkah yaitu: Heuristik, Kritik, Interpretasi, dan Historiografi. Adapun teknik yang digunakan dalam pengumpulan data yaitu studi literatur dengan mengkaji sumber-sumber literatur yang relevan dengan permasalahan yang dikaji. Berdasarkan hasil kajian, maka hasil yang didapat ialah bahwa Pertama Pemerintah Orde Baru menerapkan kebijakan asimilasi dilatarbelakangi oleh munculnya ide asimilasi dari tokoh-tokoh Tionghoa dan menjadikan ide tersebut sebagai kebijakan resmi negara untuk menyelesaikan permasalahan etnis Tionghoa yang sudah lama terjadi di Indonesia. Kedua kebijakan asimilasi pada bidang sosial budaya pada pelaksanaannya terdapat beberapa kendala yang menyebabkan terhambatnya proses asimilasi. Ketiga kebijakan asimilasi pada bidang sosial budaya memberikan dampak negatif yaitu terbatasnya ruang gerak etnis Tionghoa di Indonesia di berbagai bidang kehidupan, serta dampak positif dalam membangun masyarakat yang multikultur. Dengan hasil kajian tersebut dapat terlihat bahwa rasa saling menghargai dan menghormati sangat diperlukan untuk terciptanya kerukunan dan keselarasan antar masyarakat dalam kehidupan bernegara.

Kata Kunci: Etnis Tionghoa, Kebijakan Asimilasi, Orde Baru

Author correspondence

Email: chessiagi@gmail.com

Available online at http: // http://ejournal.upi.edu/index.php/factum 


\section{PENDAHULUAN}

Etnis Tionghoa merupakan salah satu etnis yang ada di Indonesia, etnis Tionghoa merupakan imigran yang lebih dulu datang sebelum masuknya bangsa Eropa ke Nusantara. Mereka datang dan hidup berdampingan dengan masyarakat pribumi. Sebagaimana yang diungkapkan oleh Coppel (1994, hlm. 21) bahwa pemukiman-pemukiman kecil orang Tionghoa sudah ada di Indonesia jauh sebelum kedatangan orang Eropa, terutama di bandar-bandar perdagangan di sepanjang pantai utara pulau Jawa. Keharmonisan yang terjalin tersebut tidak bertahan lama sejak kedatangan Bangsa Belanda ke Nusantara. Belanda menganggap bahwa keharmonisan yang terjadi antara etnis Tionghoa dengan masyarakat pribumi membahayakan posisi mereka, maka dari itu Belanda menerapkan strategi untuk memisahkan kedua golongan ini dengan membentuk stratifikasi dalam masyarakat. Pertama, yaitu golongan Eropa khususnya Belanda, kedua golongan Timur Asing, dan yang terakhir adalah masyarakat pribumi. Terdapat beberapa faktor dalam penerapan politik pemisahan tersebut, di samping untuk memudahkan pengawasan administrasi sipil, pemisahan tersebut dilakukan dengan tujuan propaganda pemerintah kolonial untuk menjauhkan hubungan antara etnis Tionghoa dengan masyarakat pribumi. Sebagaimana yang diungkapkan oleh Setiono (2008) bahwa:

Belanda pun mengeluarkan berbagai kebijaksanaan dan peraturan yang bertujuan memisahkan etnis Tionghoa dengan penduduk setempat. Antara lain dengan mengeksklusifkan tempat tinggal tempat tinggal mereka dan memberi orang-orang Tionghoa hak-hak untuk memungut pajak, menjual candu, dan membuka rumah judi yang sangat merugikan penduduk setempat. Membagibagi kedudukan hukum penduduk Indonesia dengan dasar yang sangat rasial. Antara lain dengan menempatkan posisi etnis Tionghoa sebagai warga vreemdeoosterlingen (timur asing) lebih tinggi dari golongan inlander atau pribumi (hlm. 83).

Terlebih saat Belanda membuat sistem pemukiman yang disebut dengan wijkenstelsel yang dikhususkan oleh etnis Tionghoa. Sistem pemukiman tersebut pada mulanya bertujuan untuk mempermudah pendataan sipil, akan tetapi hal tersebut menimbulkan sifat dan stereotip ekslusif di kalangan Tionghoa. Dari hal-hal tersebut merupakan salah satu latar belakang munculnya berbagai stereotip negatif di mata masyarakat pribumi terhadap etnis Tionghoa. Dari sinilah keharmonisan yang terjalin tersebut pada akhirnya renggang.

Sejak terciptanya stereotip tersebut permasalahan Tionghoa semakin banyak terjadi dan berkelanjutan dalam periodeperiode selanjutnya. Dalam penelitian ini bermaksud mengkaji upaya penyelesaian masalah Tionghoa yang telah lama terjadi, khususnya pada periode Orde Baru berdasarkan kurun waktu 19661998. Pemilihan kurun waktu tersebut dikarenakan pada saat itu Pemerintah Orde Baru menerapkan sistem kebijakan asimilasi untuk meleburkan kebudayaan etnis Tionghoa ke dalam budaya masyarakat pribumi demi tercapainya 
keselarasan dalam berwarganegara, serta untuk menghilangkan stereotip-stereotip negatif yang telah melekat pada etnis Tionghoa. Pada pelaksanaannya, kebijakan asimilasi yang diterapkan Pemerintah Orde Baru menemui beberapa kendala. Aturan-aturan yang harus dilakukan untuk melakukan asimilasi tersebut cenderung diskriminatif dan membatasi ruang gerak kehidupan etnis Tionghoa.

Pada prosesnya kebijakan asimilasi tersebut diterapkan terfokus pada bidang sosial budaya, namun dalam pelaksanaannya kebijakan asimilasi inijuga diterapkan di seluruh bidang kehidupan etnis Tionghoa di Indonesia. Akan tetapi dalam penelitian ini, peneliti terfokus pada bidang sosial budaya saja, karena bidang tersebut yang memiliki pengaruh besar terhadap identitas dan eksistensi kebudayaan Tionghoa di Indonesia. Pada pelaksanaannya, kebijakan asimilasi tersebut pun memberi dampak yang signifikan terhadap keberadaan etnis Tionghoa di Indonesia maupun terhadap pemerintahan itu sendiri, dampak yang ditimbulkan pun beragam. Di sisi lain kebijakan asimilasi total memberikan dampak negatif, akan tetapi di sisi lain juga memberikan dampak positif. Dalam hal ini, Indonesia merupakan salah satu negara yang menerapkan kebijakan asimilasi terhadap etnis Tionghoa di Asia Tenggara selain Filipina, Thailand, dan Vietnam, namun penerapan kebijakan asimilasi di Indonesia merupakan yang paling radikal ditinjau dari kebijakan-kebijakan yang pernah diterapkan dalam menyelesaikan masalah etnis Tionghoa.
Berangkat dari permasalahan tesebut, penelitian ini berjuan untuk mengetahui bagaimana dinamika kehidupan dan posisi etnis Tionghoa pada saat itu ketika terhimpit kebijakan asimilasi yang diterapkan oleh Pemerintah Orde Baru. Berdasarkan pokok-pokok latar belakang masalah tersebut, masalah utama yang akan dikaji dalam penelitian ini ialah bagaimana Pemerintah Orde Baru menerapkan kebijakan asimilasi terhadap etnis Tionghoa di Indonesia pada tahun 1966-1998. Masalah utama tersebut kemudian terbagi ke dalam tiga rumusan masalah yaitu pertama mengenai apa yang melatarbelakangi Pemerintah Orde Baru membuat kebijakan asimilasi terhadap etnis Tionghoa. Kedua, bagaimana implementasi kebijakan asimilasi oleh Pemerintah Orde Baru terhadap etnis Tionghoa di bidang sosial budaya. Ketiga, bagaimana dampak kebijakan asimilasi yang diterapkan Pemerintah Orde Baru terhadap etnis Tionghoa di Indonesia di bidang sosial budaya. Dengan adanya penelitian ini diharapkan dapat menambah khazanah penulisan mengenai Sejarah Indonesia khususnya mengenai kehidupan etnis Tionghoa di Indonesia pada masa Pemerintahan Orde Baru, sebagai bahan pengembangan materi dan diskusi, serta sebagai bahan pertimbangan, pemikiran, dan perbandingan dalam penelitian sejarah selanjutnya, khususnya mengenai sejarah masa Orde Baru.

\section{METODE PENELITIAN}

Dalam mengakaji permasalahan dalam penelitian ini, peneliti menggunakan 
metode historis yang terdiri dari empat langkah, yaitu heuristik, kritik sumber, interpretasi, dan historiografi. Tahap pertama, yaitu heuristik yang merupakan pencarian dan pengumpulan sumber sejarah yang relevan (Ismaun, 2005, hlm. 49). Pada tahap ini peneliti mencari dan mengumpulkan sumber-sumber sejarah yang berkaitan dengan topik penelitian. Sumber tersebut dapat berupa arsip, buku, dokumen, surat kabar, dan lain sebagainya. Dalam penelitian ini, peneliti mendapatkan sumber-sumber melalui perpustakaan, toko buku, maupun institusi yang memungkinkan tersedianya sumber-sumber sejarah yang relevan dengan penelitian ini. Langkah kedua yaitu kritik sumber, yang merupakan tahap dimana peneliti memberikan penilaian terhadap sumber-sumber sejarah yang telah diperoleh. Kritik sumber memiliki dua jenis, yaitu kritik eksternal dan kritik internal. "Dalam hal ini, dilakukan uji keabsahan tentang keaslian sumber (autentitas) yang dilakukan melalui kritik ekstern dan keabsahan tentang kesahihan sumber (kredibilitas) yang ditelusuri melalui kritik intern" (Abdurahman, 2007, hlm. 68). Penilaian sumber tersebut dilakukan guna mengetahui dan menguji kredibilitas dari sumber yang akan digunakan apakah sumber tersebut layak untuk dijadikan bahan referensi pada penelitian ini.

Langkah ketiga yaitu interpretasi yang merupakan tahap menafsirkan fakta-fakta sejarah. "Dalam hal ini, ada dua metode yang digunakan, yaitu analisis dan sintesis. Analisis berarti menguraikan, sedangkan sintesis berarti menyatukan. Keduanya dipandang sebagai metode utama dalam interpretasi” (Kuntowijoyo, 1995, hlm. 100). Pada proses interpretasi ini peneliti melakukan analisis kritis terhadap sumbersumber yang telah diperoleh, dalam tahap ini peneliti memberikan komentar dan pandangannya terhadap sumber-sumber yang telah diperoleh. Langkah terkahir dalam metode historis ialah historiografi yang merupakan tahap penulisan hasil penelitian. Tahap ini merupakan tahap terakhir dari metode penelitian sejarah. "Layaknya laporan penelitian ilmiah, penulisan hasil penelitian sejarah hendaknya dapat memberikan gambaran yang jelas mengenai proses penelitian dari awal (fase perencanaan) sampai dengan akhir (penarikan kesimpulan) (Abdurahman, 2007, hlm. 76). Pada tahap ini peneliti berusaha untuk menuangkan hasil pemikiran dan pandangannya terhadap sumber-sumber yang telah diperoleh ke dalam suatu tulisan dan disusun ke dalam satu karya tulis ilmiah, dalam hal ini ialah skripsi. Penulisan skripsi ini kemudian akan menajdi suatu tulisan yang tersusun secara sistematis setelah melewati rangkaian metode ilmiah, yaitu metode sejarah atau metode historis.

Pada penelitian skripsi ini, peneliti akan menggunakan pendekatan interdisipliner. Dengan begitu, peneliti akan menggunakan ilmu-ilmu bantu dalam mengkaji penelitian pada skripsi ini. Ilmu bantu yang digunakan ialah Sosiologi, dan Antropologi. Konsep-konsep sosiologi diperlukan untuk mengkaji perubahan sosial dan stratifikasi yang terjadi pada etnis Tionghoa di Indonesia. Selain itu, konsep-konsep antropologi 
juga diperlukan dalam membahas dan mengkaji bentuk-bentuk pembauran yang terjadi pada etnis Tionghoa di Indonesia, salah satunya ialah konsep asimilasi.

\section{HASIL PENELITIAN DAN PEMBAHASAN}

Diterapkannya kebijakan asimilasi oleh Pemerintah Orde Baru sesungguhnya bertujuan untuk menyelesaikan permasalahan etnis Tionghoa yang sejak lama terjadi di Indonesia. Kebijakan asimilasitersebutterinspirasidariidetokohtokoh Tionghoa mengenai pembauran total sebagai solusi dari berbagai permasalahan yang ada, meskipun pada prosesnya, golongan pendukung asimilasi ini harus berhadapan dengan golongan pendukung konsep "integrasi". Akan tetapi, setelah Orde Baru berdiri, golongan asimilasionis mendapatkan kemenangan mutlak, yaitu konsep asimilasi dijadikan kebijakan resmi negara. Hal tersebut dapat terlihat pada Sidang Umum MPRS tahun 1966 bahwa usulan asimilasi mendominasi dan dapat diterima. Hal tersebut menandakan bahwa asimilasi telah resmi dijadikan sebagai kebijakan negara pada Pemerintahan Orde Baru. Sidang Umum MPRS tersebut pada akhirnya menyoroti tiga keputusan mengenai etnis Tionghoa. Sebagaimana yang dijelaskan oleh Suryomenggolo (2003, hlm. 77) mengenai resolusi etnis Tionghoa adalah sebagai berikut: (a) Resolusi MPRSno.III/MPRS/1966tentang Pembinaan Kesatuan Bangsa. Melalui salah satu pasalnya, resolusi ini secara eksplisit menyatakan asimilasi sebagai satu-satunya jalan bagi etnis Tionghoa untuk meleburkan diri; (b) Resolusi MPRS no. XXVII/MPRS/1966 tentang Agama, Pendidikan, dan Kebudajaan. Resolusi ini secara tegas mendesak Pemerintah untuk mengeluarkan UU larangan terhadap sekolah-sekolah asing dan agar pemerintah membina kebudayaan daerah-daerah; (c) Resolusi MPRS no. XXXII/MPRS/1966 tentang pembinaan pers. Resolusi ini menyatakan bahwa penerbitan pers dalam bahasa Tionghoa menjadi monopoli pemerintah. Surat kabar "Harian Indonesia" diterbitkan sehubungan dengan itu.

Setelah diresmikan, kebijakan asimilasi kemudian diimplementasikan di berbagai bidang kehidupan, diantaranya sosial budaya, pendidikan, politik, kewarganegaraan, dan ekonomi. Khusus pada pembahasa penelitian ini ialah pada bidang sosial budaya, pemerintah mengeluarkan peraturan yang berisi untuk memperpanjang kebijakan ganti nama yang pada periode sebelumnya telah dilaksanakan. Hal tersebut menjadi bahan pertimbangan untuk mengganti nama sebagaimana yang tertuang pada Arsip Keputusan Presiden No. 123 tahun 1968 tentang Memperpanjang Masa Berlakunya Peraturan Ganti Nama Bagi Warganegera Indonesia yang Memakai Nama Cina bahwa "di dalam rangka nation dan character building Indonesia dipandang perlu mempercepat proses asimilasi warganegara Indonesia keturunan asing ke dalam tubuh bangsa Indonesia". "Seorang yang umpamanya bernama "Tan" dapat memakai nama "Tanojo", "Ong” dijadikan “Onggowasito”, dan lain-lain (Ham, 2005, 
hlm. 157). Kebijakan mengganti nama ini menuai kontroversi dari kalangan etnis Tionghoa sendiri, sebagian dari mereka menganggap bahwa tidak ada kaitannya dengan mengganti nama, maka seorang individu dapat dikatakan seorang yang nasionalis.

Pada pelaksanaannya, kebijakan ganti nama menimbulkan beberapa masalah bagi etnis Tionghoa itu sendiri. Bagi etnis Tionghoa yang mengganti namanya, mereka kesulitan untuk mengingat dan membiasakan diri dengan nama barunya tersebut, bahkan seringkali mereka lupa akan nama sesama kerabatnya yang juga turut mengganti nama. Hal tersebut menyebabkan mereka harus beradaptasi kembali dengan mengingat nama-nama baru yang digunakan, serta tidak jarang pada kehidupan sehari-hari pada akhirnya mereka tetap menggunakan nama lamanya karena dirasa sudah banyak orang yang mengenalnya dengan nama itu. Di samping itu, pemilihan nama yang sesuai menjadi salah satu kendala. Etnis Tionghoa seringkali kebingungan dalam menentukan nama apa yang akan mereka pilih sebagai nama barunya, terkadang mereka mengambil nama-nama yang berasal dari Bahasa Jawa, namun nama tersebut memiliki arti yang kurang baik ataupun tidak boleh dipakai bagi sembarang orang. "Nama-nama itu telah dipilih demikian terburu-buru sehingga beberapa diantaranya ditolak karena tidak sesuai (sebab misalnya, nama-nama itu mempunyai hubungan kebangsawanan, seperti misalnya Kusuma atau Ningrat) dan beberapa lagi mendapat ejekan karena bunyinya yang aneh" (Coppel, 1994, hlm.
168). Selain itu, kebijakan mengganti nama ini tidak begitu mencerminkan rasa nasionalis dari etnis Tionghoa Indonesia. Sebagian dari mereka bahkan hanya "ikutikutan" dan bukan karena hati nurani ingin mengganti namanya. Tidak berdasar pula faktor apa yang akan mendorong mereka berasimilasi dengan cepat dengan mengganti namanya tersebut. Sebagaimana yang diungkapkan oleh Jahja (1987) bahwa:

Apa jaminan kalau namanya diganti lalu si Warno jadi nasionalis dan patriot sejati? Kalau dasarnya culas dan mata duitan, biar ganti nama seribu kali juga tidak menolong. Yang penting, warga negara pelbagai keturunan bertintegrasi secara politik dan ideologi nasional yang kokoh, punya rasa cinta tanah air yang tulus. Soal kawin sama siapa dan bernama siapa, sungguh tidak penting (hlm. 38).

Selain mengganti nama, pemerintah juga mengeluarkan kebijakan pada bidang agama, kepercayaan, dan adat istiadat kemudian ditindak lanjuti dengan dikeluarkannya Instruksi Presiden Republik Indonesia No. 14 Tahun 1967yang ditetapkan pada tanggal 6 Desember 1967. Kebijakan tersebut dikeluarkan atas dasar pemikiran bahwa agama kepercayaan dan adat istiadat etnis Tionghoa jika dilakukan di depan umum dapat mempengaruhi keadaan psikologis, mental dan moril yang kurang wajar terhadap masyarakat Indonesia, maka dari itu hal tersebut dapat menghambat berlangsungnya kebijakan asimilasi. Dalam peraturan tersebut, khususnya dalam bidang agama, etnis Tionghoa dilarang untuk melakukan atau menunaikan ibadah di tempat terbuka, 
artinya mereka hanya diperbolehkan untuk melaksanakan ibadah dalam lingkungan tertutup terbatas hanya pada lingkungan keluarga atau perorangan saja. Sebagaimana yang dijelaskan oleh Jahja (1998, hlm. 87) bahwa (1) Tanpa mengurangijaminan keleluasaan memeluk agama dan menunaikan ibadatnya, tatacara ibadah Cina yang memiliki aspek affinitas kultural yang berpusat pada negeri leluhurnya, pelaksanaannya harus dilakukan secara intern dalam hubungan keluarga atau perorangan; (2) Perayaanperayaan pesta agama dan adat istiadat Cina dilakukan dalam lingkungan keluarga.

Hal tersebut memberikan dampak yang signifikan terhadap kehidupan etnis Tionghoa di Indonesia, karena agama mereka tidak diakui maka dari itu mereka mendapatkan beberapa kendala dalam pembuatan KTP (Kartu Tanda Penduduk) yang mengharuskan pembuatnya mencantumkan agama yang dianutnya. Selain itu, mereka juga mendapatkan kendala dalam surat nikah dan tata cara pernikahan yang akan dijalaninya. Untuk menjamin keamanan, etnis Tionghoa memilih untuk mencamtumkan agama lain dalam KTP maupun surat nikahnya tersebut, yaitu agama Buddha Tridharma. Sebagaimana yang diungkapkan Adam (2005, tanpa halaman) bahwa yang masih terasa diskriminatif adalah soal perkawinan. Dalam banyak kasus, perkawinan umat Khonghucu tidak diakui untuk dicatat pada Kantor Catatan Sipil.

Kebijakan asimilasi di bidang sosial budaya tidak berhenti hanya disitu, akan tetapi berlanjut kepada kebijakan media.
Sejalan dengan hasil Sidang Umum MPRS yang tertuang pada Resolusi MPRS no. XXXII/MPRS/1966 tentang pembinaan pers. Dalam resolusi tersebut memperlihatkan bahwa pers Tionghoa berada dibawah binaan pemerintah. Hal tersebut tidak terlepas dari peraturan yang melarang penggunaan Bahasa dan tulisan Mandarin secara terbuka, bahwasanya setiap surat kabar Tionghoa pasti memakai Bahasa Mandarin yang pada saat itu telah dilarang untuk digunakan. Berkenaan dengan kebijakan tentang pelarangan digunakannya Bahasa Mandarin di depan umum tersebut, maka pemerintah juga melarang segala bentuk media yang berbahasa Mandarin, sebagaimana yang diungkapkan Dawis (2010) tentang Larangan Mengimpor, Memperdagangkan, dan Mengedarkan Semua Jenis Barang Cetakan dalam Bahasa dan Aksara Cina, ditetapkan pada tahun 1978, bahwa:

Dianggap perlu untuk melarang pengimporan, perdagangan, dan pengedaran semua jenis barang cetakan dalam Bahasa dan aksara Cina yang berasal dari luar negeri... untuk memupuk dan mengembangkan kebudayaan Indonesia demi keutuhan dan kesatuan bangsa dan peningkatan pembangunan Bahasa nasional. Keputusan ini selanjutnya merumuskan "barang cetakan" sebagai buku, majalah, selebaran, dan koran yang dicetak dalam Bahasa dan akara Cina, yang berasal dari luar negeri." (hlm. 110).

Selain media surat kabar, media perfilman juga menjadi salah satu sorotan pemerintah. "In order to further curtail 
Chinese cultural influence, the Jakarta Movie Censor Board ruled that Chinese characters were not to be allowed in Madarin movie advertisements, and the government even considered restricting the importation of Hong Kong and Taiwanmade movies (Suryadinata, 1976, hlm. 781). Pemerintah melarang segala bentuk film ataupun media yang menggunakan Bahasa Mandarin ataupun tulisan Tionghoa untuk masuk ke Indonesia. Bahkan terdapat peraturan dalam bandara yang melarang orang asing untuk membawa segala bentuk media yang berhubungan dengan Bahasa dan tulisan Mandarin ke Indonesia. Dalam pelaksanaannya pelarangan masuknya film Tionghoa ini mengalami kendala di beberapa daerah karena dengan diterapkannya pelarangan tersebut berdampak kepada pengurangan pendapatan daerah. Selain itu sejak munculnya saluran televisi-televisi swasta pada tahun 1988 membuat peraturan mengenai pelarangan masuknya film Tionghoa ini semakin sulit. Sen \& Hill (dalam Dawis, 2010) mengungkapkan bahwa:

RCTI, stasiun televisi swasta pertama, mulai memancar di udara pada tahun 198 dengan hampir 90\% acaranya yang diimpor. Tetapi pesaingnya, SCTV, yang mulai siaran pertamanya pada tahun 1989, menyajikan film-film Hong Kong dan Taiwan yang disulihsuarakan dalam bahasa nasional - Bahasa Indonesia (hlm. 129).

Dengan dilarangnya berbagai media dalam menampilkan tulisan dan Bahasa Mandarin, maka hal tersebut berdampak kepada hilangnya kemampuan orang
Tionghoa dalam menulis, membaca, dan berbahasa Mandarin. Kendala tersebut sering ditemui pada etnis Tionghoa generasi muda, karena media sebagai sumber belajar mereka telah dilarang. Hal tersebut menyebabkan kekhawatiran pada golongan tua kepada anak-anaknya yang tidak memiliki kemampuan berbahasa Mandarin, karena mereka berpendapat bahwa penguasaan Bahasa sangat diperlukan untuk menunjang pekerjaan di masa depan. Karena berbagai media yang berbahasa Mandarin telah dilenyapkan, maka pengajaran mengenai Bahasa Mandarin diintensifkan pada kehidupan sehari-hari terbatas pada lingkungan keluarga saja.

\section{SIMPULAN}

Berdasarkan pembahasan yang telah dikaji sebelumnya, dapat terlihat bahwa kebijakan asimilasi yang diterapkan oleh Pemerintah Orde Baru terhadap etnis Tionghoa di Indonesia memberikan dampak yang signifikan terhadap dinamika kehidupan etnis Tionghoa, khususnya pada bidang sosial budaya. Penerapan kebijakan asimilasi yang cenderung dipaksakan pada prosesnya seringkali menyulitkan etnis Tionghoa itu sendiri. Penerapan kebijakan asimilasi terhadap etnis Tionghoa oleh Pemerintah Orde Baru secara langsung menutup rapat segala ruang gerak etnis Tionghoa dalam berbagai bidang kehidupan. Selain karena untuk terciptanya asimilasi total, pemerintah menggunakan kebijakan asimilasi ini sebagai media pengawas gerak-gerik etnis Tionghoa di Indonesia. 
Sejauh ini dalam pengamatan peneliti, diterapkannya kebijakan asimilasi dalam bidang sosial budaya etnis Tionghoa di Indonesia secara perlahan mengikis kebudayaan yang dimiliki etnis Tionghoa. Ruang gerak mereka begitu dibatasi hingga mereka pun tidak mampu untuk melawan kebijakan yang menghimpit serta sangat menguras tenaga mereka itu. Banyak faktor yang melatarbelakangi hal tersebut, bahwasanya mereka tidak dapat melawan kekuatan pemerintahan cenderung otoriter yang berlindung di balik kebijakan asimilasi tersebut, karena mereka tidak ingin dianggap sebagai pemberontak dan mereka tidak ingin dipenjara. Selain itu, mereka tidak ingin stereotip yang menyatakan bahwa mereka itu golongan eksklusif dan tidak membaur semakin melekat kuat, maka dari itu mereka memilih untuk mengikuti kebijakan asimilasi yang diterapkan oleh pemerintah, meskipun banyak kendala yang harus mereka hadapi. Hal tersebut menyebabkan tertutupnya ruang gerak etnis Tionghoa, khususnya dalam bidang sosial budaya. Kedudukan mereka terbatas serta hanya bisa melakukan segala peraturan yang telah ditetapkan oleh pemerintah meskipun hal tersebut di satu sisi menjadi beban bagi kehidupan mereka.

Demikianlah kebijakan asimilasi Pemerintah Orde Baru dalam bidang sosial budaya menyebabkan pengikisan budaya yang berlarut-larut terhadap etnis Tionghoa. Meskipun tidak dapat dipungkiri terdapat dampak-dampak positif yang terjadi selama masa penerapan asimilasi tersebut. "Kebijakan asimilasi total - di sisi lain - ternyata justru telah melahirkan dampak positif bagi sebagian orang-orang Tionghoa, setidaknya buat pelakunya sendiri, yaitu berlangsungnya pembauran antara mereka dengan masyarakat pribumi melalui proses yang lebih alamiah" (Afif, 2012, hlm. 141). Akan tetapi dampak negatif lebih dominan terlihat pada hasil penerapan kebijakan asimilasi ini. Pengikisan budaya tersebut mengakibatkan kaburnya identitas etnis Tionghoa, bahkan cenderung tidak memiliki identitas keetnisannya. Meskipun begitu, sebisa mungkin diantara mereka yang berusaha untuk menjaga identitas Tionghoanya tersebut meskipun sudah berkurang. Pada saat ini pula sudah jarang ditemui orang-orang Tionghoa totok, ataupun orang-orang Tionghoa yang masih kental dengan budaya Tionghoa-nya. Kebanyakan dari mereka telah membaur dengan kebudayaan setempat yang sudah menjadi bagian dari kehidupannya.

\section{DAFTAR PUSTAKA}

Abdurrahman, D. (2007). Metodologi penelitian sejarah. Yogyakarta: ArRuzz Media.

Adam, A. W. (2005, 4 Februari). Diskriminasi panjang terhadap etnis Tionghoa. Kompas, tanpa halaman.

Afif, A. (2012). Identitas tionghoa muslim di Indonesia. Depok: Kepik.

Coppel, C. A. (1993). Tionghoa indonesia dalam krisis. Jakarta: Sinar Harapan.

Dawis, A. (2010). Orang Indonesia tionghoa mencari identitas. Jakarta: Gramedia Pustaka Utama.

Ismaun, (2005). Sejarah sebagai ilmu. Bandung: Historia Utama Press.

Ham, O, H. (2005). Riwayat tionghoa 
peranakan di Jawa. Jakarta: Komunitas Bambu.

Jahja, J. editor. (1987). Ganti nama. Jakarta: Yayasan Tunas Bangsa.

Jahja, J. (1998). Masalah orang tionghoa di Indonesia: kapok jadi nonpri. Bandung: Zaman Wacana Mulia.

Kuntowijoyo. (1995). Metodologi sejarah. Yogyakarta: Tiara Wacana.
Suryadinata, L. (1976). Indonesian policies towards the Chinese minority under the new order. Asian Survey, Vol. 6, (8). Suryomenggolo, J. (2003). Hukum sebagai alat kekuasaan: politik asimilasi orde baru. Jakarta: Galang Press, Elkasa.

Setiono, B. G. (2008). Tionghoa dalam pusaran politik. Jakarta: Trans Media. 